\title{
Source levels of dugong (Dugong dugon) vocalizations recorded in Shark Bay
}

\author{
Miles J. G. Parsons ${ }^{\text {a) }}$ \\ Centre for Marine Science and Technology, Curtin University, GPO Box U1987, Perth, \\ Western Australia 6845, Australia \\ Dave Holley \\ Department of Environment and Conservation, Shark Bay District Office, 61-63 Knight Terrace, Denham, \\ Western Australia 6537, Australia \\ Robert D. McCauley \\ Centre for Marine Science and Technology, Curtin University, GPO Box U1987, Perth, \\ Western Australia 6845, Australia
}

(Received 14 July 2012; revised 30 May 2013; accepted 10 June 2013)

\begin{abstract}
Dugongs (Dugong dugon) spend significant time in shallow, turbid waters and are often active at night, conditions which are not conducive to visual cues. In part, as a result, dugongs vocalize to gain or pass information. Passive acoustic recording is a useful tool for remote detection of vocal marine animals, but its application to dugongs has been little explored compared with other mammals. Aerial surveys, often used to monitor dugong distribution and abundance, are not always financially or logistically viable and involve inherent availability and perception bias considerations. Passive acoustic monitoring is also subject to sampling biases and a first step to identifying these biases and understanding the detection or communication range of animal calls is to determine call source level. In March 2012, four dugongs were fitted with satellite tags in Shark Bay, Western Australia by the Department of Environment and Conservation. During this, acoustic recordings were taken at $5.1 \mathrm{~m}$ range. Source levels for each of five call types (two types of chirp, bark, squeak, and quack) were estimated, assuming spherical spreading as the transmission loss. Mean source levels for these call types were $139(n=19), 135(12), 142(2), 158(1)$, and $136(9) \mathrm{dB}$ re $1 \mu \mathrm{Pa}$ at $1 \mathrm{~m}$, respectively. (C) 2013 Acoustical Society of America. [http://dx.doi.org/10.1121/1.4816583]
\end{abstract}

PACS number(s): 43.30.Sf, 43.80.Ka, 43.60.Jn, 43.64.Tk [JJF] Pages: 2582-2588

\section{INTRODUCTION}

The dugong (Dugong dugon) is an aquatic herbivore and one of four members on the order of Sirenia (Marsh et al., 2002; Dexler and Freund, 1906). Globally, dugongs are listed as vulnerable on the IUCN red list, however, in Australia the populations are maintaining numbers (Marsh, 2008). In Western Australia, Shark Bay, a World Heritage Property, plays host to around 10000 individuals, one of the largest and most secure populations of dugong in the world (Department of Environment and Conservation, 2010).

Dugongs are often solitary creatures and spend much of their time in shallow waters (Chilvers et al., 2004) where they feed on multiple seagrass species, such as those spread across Shark Bay (Walker et al., 1988). In winter the Shark Bay population can be spread out with many dugongs residing in deeper waters between 5-15 $\mathrm{m}$ depth, in part to shelter from tiger sharks (Galeocerdo cuvier). By contrast, in summer they can herd in large numbers, for example, in Gladstone Bay, on the eastern gulf of Shark Bay (Anderson, 1986; Holley, 2006; Wirsing et al., 2007a,b). Thus monitoring the Shark Bay dugong population is often easier in the summer when numbers can be more concentrated.

\footnotetext{
a) Author to whom correspondence should be addressed. Electronic mail: m.parsons@cmst.curtin.edu.au
}

However, surveying only at this time does not inform the observer on overall annual movements and numbers of the population.

Aerial, boat-based, and land-based visual surveys have become standard tools to census dugong populations. However, these can be financially and logistically intensive and can involve significant availability and perception bias, particularly in deeper or more turbid waters (Pollock et al., 2004, 2006). Additionally, visual surveys are impractical at night when dugongs have been shown to be active (Anderson, 1986; Ichikawa et al., 2006). Therefore complementary, alternative techniques can add, and possibly fill gaps, in the data collected by visual survey. Passive acoustic monitoring of marine species from their vocalizations also involves inherent availability and perception bias. An animal has to be vocal and within the hydrophone detection range to be available and sounds have to be correctly identified by the observer as originating from a dugong. Nevertheless, under certain circumstances passive acoustic techniques have been shown to improve detection in visual surveys of dugongs (Ichikawa et al., 2009, 2010).

Sirenia possess small eyes with poor eyesight which function best at low light levels, suggesting little emphasis on visual cues as a form of communication (Dexler and Freund, 1906; Piggins et al., 1983). These developed traits are possibly due to the often turbid environments they 
inhabit (Holley, 2006) and predominant orientation and head position. As such, acoustic cues are of benefit to the species and indeed, Anderson and Barclay (1995) categorized three types of dugong "bird-like" calls as chirps (frequency-modulated signals in the $3-18 \mathrm{kHz}$ range with two or more harmonics, lasting less than $60 \mathrm{~ms}$ ), trills (frequency-modulated calls lasting up to $2.2 \mathrm{~s}$, over a $740 \mathrm{~Hz}$ bandwidth, in the $3-18 \mathrm{kHz}$ range), and barks (broadband signals between $500 \mathrm{~Hz}$ and $2.2 \mathrm{kHz}$, lasting up to $120 \mathrm{~ms}$ ). Similar dugong calls have been reported in Asia (Ichikawa et al., 2003; Ichikawa et al., 2006; Ichikawa et al., 2009; Ichikawa et al., 2010, 2011; Okumura et al., 2007), Australia (Ichikawa et al., 2012), and in captivity (Marsh et al., 1978). The most frequently detected calls are chirps, accounting for approximately $90 \%$ of all calls (Ichikawa et al., 2003; Ichikawa et al., 2006; Okumura et al., 2007; Hishimoto et al., 2005).

While the functional role of dugong calls has been little examined, acoustic signals by marine mammals are often suggested to serve as a method of maintaining communication in group active spaces or between mother and calf (Sousa-Lima et al. 2002; Janik et al., 2006; Jensen et al., 2012), or as a warning of predators (Deecke et al., 2002). Identifying the acoustic characteristics of these calls, such as source level (SL) not only helps understand biases associated with passive acoustic monitoring of marine animals and distance sampling methods to measure abundance, but is also one of the first steps to understanding how the callers and recipients utilize their habitat and active space (Parsons et al., 2009; Jensen et al., 2012). The aim of this study was to determine the SLs of Shark Bay dugong calls as a precursor to further ecological and abundance related research.

\section{METHODS}

On the 26th and 27th March, 2012, four dugongs were captured by members of the Department of Environment and Conservation (DEC) from a $5 \mathrm{~m}$ Zodiac vessel, as part of a James Cook University managed satellite tagging program. During the process of fitting tags the dugongs were individually brought along the starboard side and secured next to the DEC vessel with the head just in front of the bow. On each occasion, a second vessel, Cuvier, of the Shark Bay Ecosystem Research Project, then pulled alongside the port side of the DEC Zodiac as additional support, typically 3 min after capture. At this stage opportunistic recordings of dugong vocalizations were acquired. All engines were shut down and an HTI 96-min hydrophone (HighTech Inc., MS, USA, $163.9 \mathrm{~dB}$ re $1 \mu \mathrm{Pa} / \mathrm{V}$ sensitivity) was suspended off the port side near the bow of the Cuvier, at a depth of approximately $0.75-1 \mathrm{~m}$. The cable was held away from the vessel to avoid contact with the hull. This configuration positioned the hydrophone level with the head of the dugong at $5.1 \mathrm{~m}$ range on the port side, at a depth of approximately $1 \mathrm{~m}$ when vocalizing. Locating the hydrophone and dugong just in front of the bows meant there was a direct path between source and receiver and no hull directly between, or above the two. Thus recordings were taken at $90^{\circ}$ to port side of the dugongs' head. The hydrophone was connected to an HR-5 Jammin pro recorder, sampling at $46 \mathrm{kHz}$, which had been calibrated using $-90 \mathrm{~dB}$ re $1 \mu \mathrm{Pa} / \mathrm{V}$ white noise with a flat response between $100 \mathrm{~Hz}$ and $23 \mathrm{kHz}$. The HR-5 recorded all noise from the moment the two stationary vessels were alongside to the time the dugong had been released and was $>25 \mathrm{~m}$ from the vessels. Acoustic data was processed using a suite of MATLAB programs developed at the Centre for Marine Science and Technology (CMST). To limit sound energy from abiotic sources and vibration of the hydrophone cable, a hi-pass filter of $100 \mathrm{~Hz}$ was applied to the data. Spectrograms were produced using 1024-point FFT with 90\% overlap, and Hanning window. Parseval's theorem was applied to calculate the total received level in the frequency band of interest. The contribution of ambient noise levels was determined and removed as per Parsons et al. (2012), with pressure levels within the 5 and $95 \%$ region of the total cumulative energy used to determine duration of the call (Malme et al., 1986). Thus the call length was taken as the time for $90 \%$ of the signal energy to pass.

The SL was calculated as the sum of the measured received level (RL) and the calculated transmission loss $(\mathrm{TL})$, where TL is a function of the range $(r)$ multiplied by an environment-dependent TL coefficient, $X$ in the form of

$$
\mathrm{SL}=\mathrm{RL}+\mathrm{TL}=\mathrm{RL}+X \log _{10}(r) .
$$

In this case $r$ was set at $5.1 \mathrm{~m}( \pm 0.1)$ with the exception of one call estimated to be at $10 \mathrm{~m}( \pm 1)$ range and spherical spreading was assumed to be the only loss, therefore $X=20$ (Urick, 1983). The RL was measured for all calls from timeaveraged power spectrum densities. The SLs and background noise levels were calculated over the $500 \mathrm{~Hz}$ to $18 \mathrm{kHz}$ bandwidth encompassing all energy.

Signal SL is often presented in a variety of formats so for comparison with other past, present, and future reports the SLs are reported here not only the call average and maximum mean squared sound pressure level (SPL) over the 95\% energy window, but also sound exposure level (SEL) and

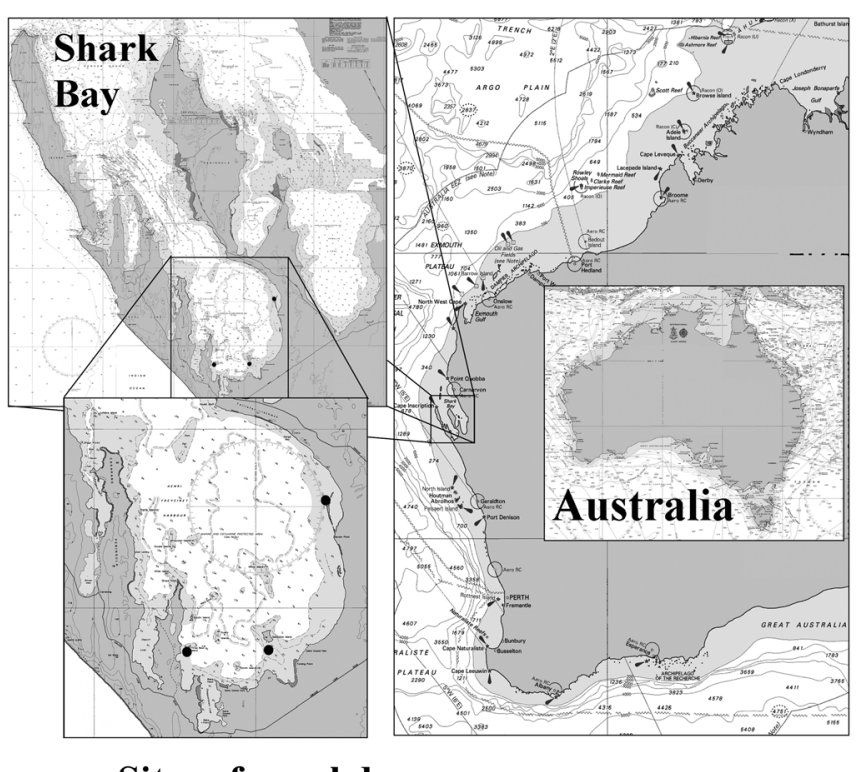

Sites of vocal dugongs

FIG. 1. Map of Western Australia showing the Shark Bay. 


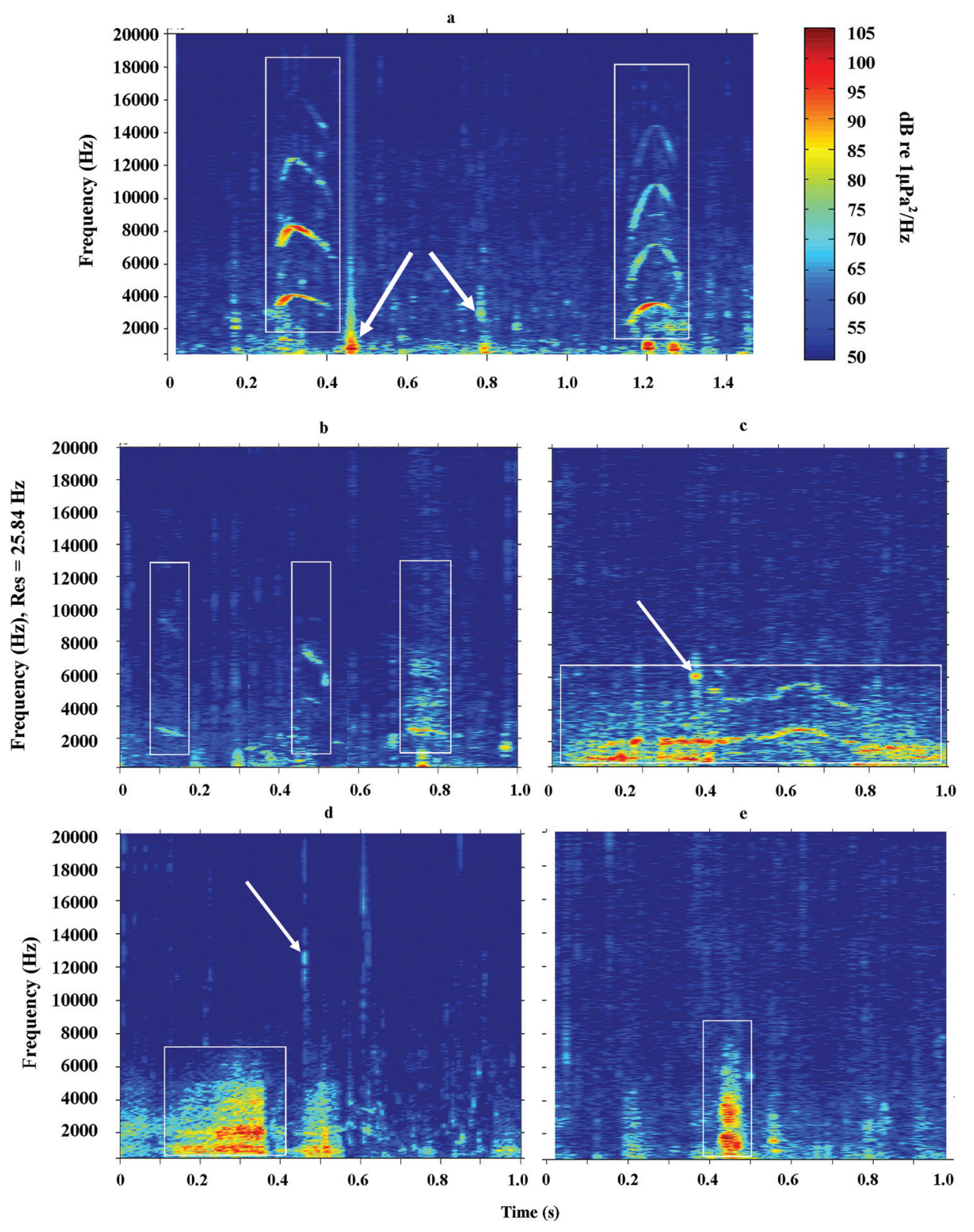

FIG. 2. Example spectrograms for five types of call produced by the dugongs including chirp 1 [(a), two calls], chirp 2 [(b), three calls], squeak (c), bark (d), and quack (e). Spectrograms produced using a 1056-point Hanning window with 0.5 overlap and frequency resolution of $25.8 \mathrm{~Hz}$.

peak-to-peak pressure for each of the dugong call types. Units of SPL, SEL, and peak-to-peak SLs were $\mathrm{dB}$ re $1 \mu \mathrm{Pa}$, $\mathrm{dB}$ re $1 \mu \mathrm{Pa}^{2} \mathrm{~s}$, and $\mathrm{dB}$ re $1 \mu \mathrm{Pa}$, respectively, with each estimated to the reference pressure at a range of $1 \mathrm{~m}$ from the source.

Calls were identified as originating from the dugong based on their similarity with previous reports and recordings of dugong calls (Anderson and Barclay, 1995; Ichikawa et al., 2003; Ichikawa et al., 2006; Ichikawa et al., 2009; Ichikawa et al., 2011) and visual confirmation of whether any other animals were present at the time of recording.

\section{RESULTS}

In total, 67 calls were recorded from three male dugongs over the course of three days of survey, at different sites in the Western Gulf of Shark Bay (Fig. 1). The two male dugongs captured on day 1 made a series of calls while next to the vessel. The first and second dugongs were 2.39 and $2.00 \mathrm{~m}$ in length and 1.55 and $1.49 \mathrm{~m}$ in girth, respectively. The dugongs were recorded in approximately $1.25 \mathrm{~m}$ of water above a flat, sandy seafloor with the first dugong over bare sand and the second over approximately $20 \%$ coverage of seagrass. Recordings of the first dugong were taken in the morning of the 26th March in calm water and with little wind with mean background noise levels at $95 \mathrm{~dB}$ re $1 \mu \mathrm{Pa}$ SPL. The second was recorded in the afternoon with increased wind and background noise (103 dB SPL). All calls from the first two dugongs were recorded with the animal at the side of the boat, i.e., at $5.1 \mathrm{~m}$ range. The third vocal dugong on the afternoon of the 28th March, produced one call in approximately $1.2 \mathrm{~m}$ of calm water over approximately $50 \%$ coverage of seagrass, at an estimated range of $10 \mathrm{~m}$ from the hydrophone, after the dugong had been released. This dugong was released without length and girth measurements being recorded. Of the 67 calls, 43 were of 
sufficient signal to noise ratio to be analyzed for call energy (32, 10, and 1 call from each dugong, respectively). The discarded calls included interference from noise such as water tapping against the hull or sounds of breaking waves, more prevalent during the recording of the second dugong when the wind had picked up. No other dugongs were visible within the area during the recordings, indeed no other animals of any kind were observed.

In total, five kinds of calls were categorized (Fig. 2, signals bounded by the white boxes), including chirps, squeaks and barks, described in previous reports [Figs. 2(a)-2(d), respectively]. Sounds most audibly likened to "quacks" were also believed to originate from the dugongs [Fig. 2(e)]. The background noise of small waves was evident with the occasional broadband signal as the hydrophone cable tapped something (Fig. 2, arrows). Only calls with 500 noise-free sample points either side of the call were examined [Figs. 3(b) and 3(c), circles before and squares after the signal]. Figure 3 highlights the 5 and $95 \%$ points of the signal cumulative energy of a "quack" ( + symbols in the waveform and cumulative energy plots), with the start and end of the call marked by the dashed lines [Figs. 3(a)-3(c)]. The energy in the spectrogram before and after these lines in Fig. 3(a) are due to the overlap used to produce the spectrogram.

Assuming spherical spreading over the 5.1 and $10 \mathrm{~m}$ ranges resulted in an estimated SL across all call types of $139 \mathrm{~dB}$ re $1 \mu \mathrm{Pa}$ at $1 \mathrm{~m}$ [ \pm 7.1 standard deviation (s.d.), $\max =159, \min =129]$. The distribution of SLs can be seen in Fig. 4. Each call type was estimated separately (Table I) with the maximum SPL at any time within any given call at
$165 \mathrm{~dB}$ re $1 \mu \mathrm{Pa}$ at $1 \mathrm{~m}$. The average SEL and peak-to-peak SLs across all calls were 124 ( \pm 8.2 s.d., $\max =146$, min$=110) \mathrm{dB}$ re $1 \mu \mathrm{Pa}^{2} \mathrm{~s}$ at $1 \mathrm{~m}$ and 150 ( \pm 7.1 s.d., $\max =180$, $\min =145) \mathrm{dB}$ re $1 \mu \mathrm{Pa}$ at $1 \mathrm{~m}$, respectively.

Two types of chirp were recorded, both of which were frequency-modulated with two or more harmonics, containing energy over the $3-18 \mathrm{kHz}$ bandwidth (fundamental frequencies shown in Table II). The first type rose and then fell in frequency, while energy from the second chirp type (effectively a downsweep) declined in frequency throughout the call (Table II). The first dugong produced 19 calls of chirp 1 and three calls of chirp 2, while the second dugong only produced nine chirp 2 calls. Though the sample size is too small to confirm significance, the chirp 1 calls were of slightly higher SL (Table I). Frequencies of the chirp 1 and 2 calls were similar, as were the chirp 2 calls of dugong 1 and 2 , but again the sample sizes are small.

Dugong 1 also produced one bark, one squeak and eight quacks, while dugong 2 produced one quack and dugong 3 only produced one bark. Both barks and quacks were broadband signals over similar frequency bands, however, the barks were significantly longer in duration and of higher SL (Table I, Table II, Fig. 2). The squeak contained a broadband section followed by a narrow bandwidth section with a single harmonic [Fig. 2(c)]. It could have been considered as a bark, immediately followed by a chirp, but while the broadband section of the squeak was similar to that of the barks, the frequency of the narrow band section was lower than that of the chirps (Fig. 2, Table II). The squeak was of similar mean SPL to that of the bark. a

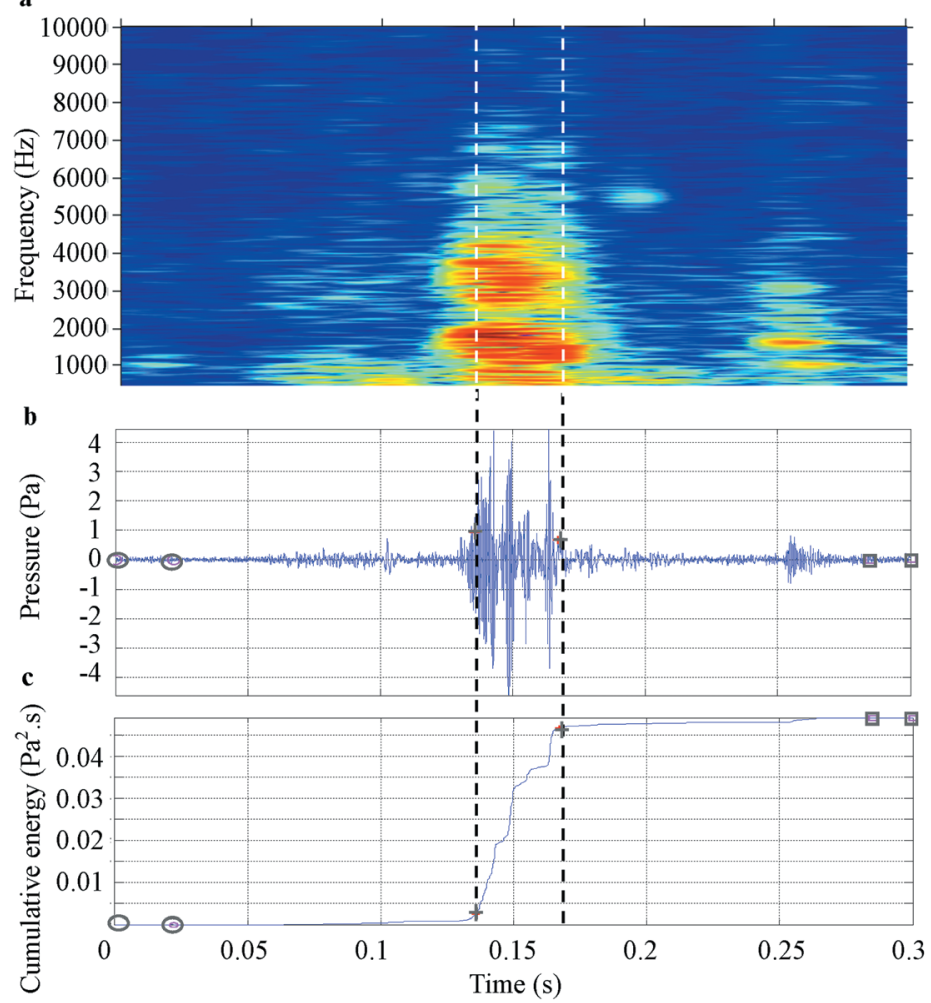

d

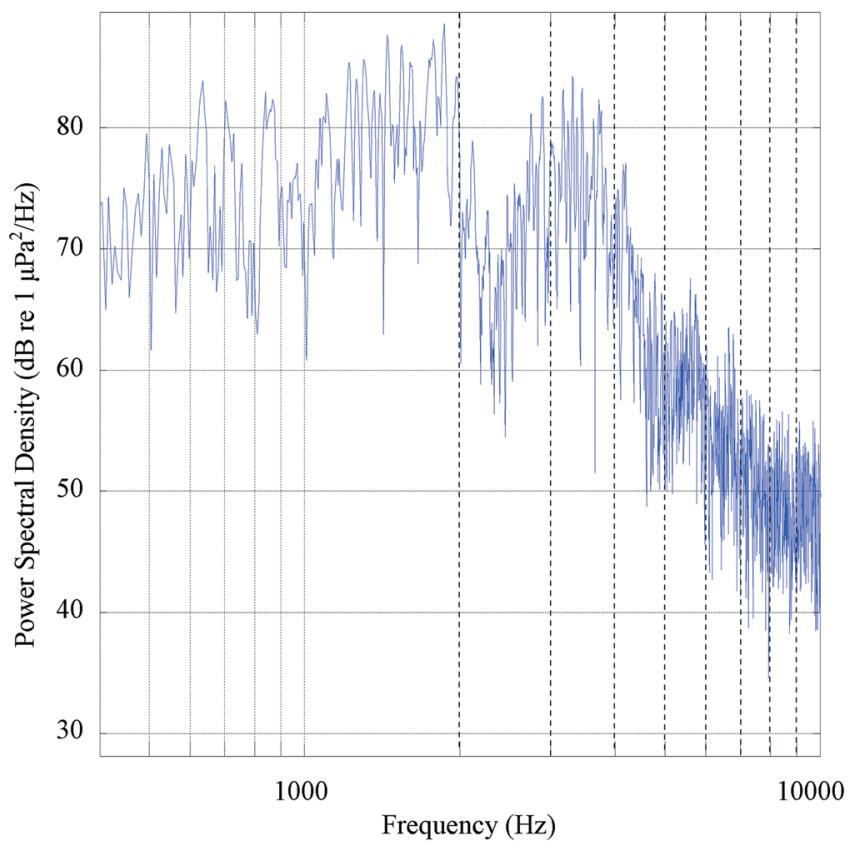

FIG. 3. Magnification of the "quack" spectrogram from Fig. 2(a), together with the respective waveform (b) and cumulative energy (c) of the call. Dashed lines represent the 5 and $95 \%$ points of the cumulative energy of the call and therefore the start and end of the call as per Malme et al. (1986). The power spectral density of the call is also shown (d). 


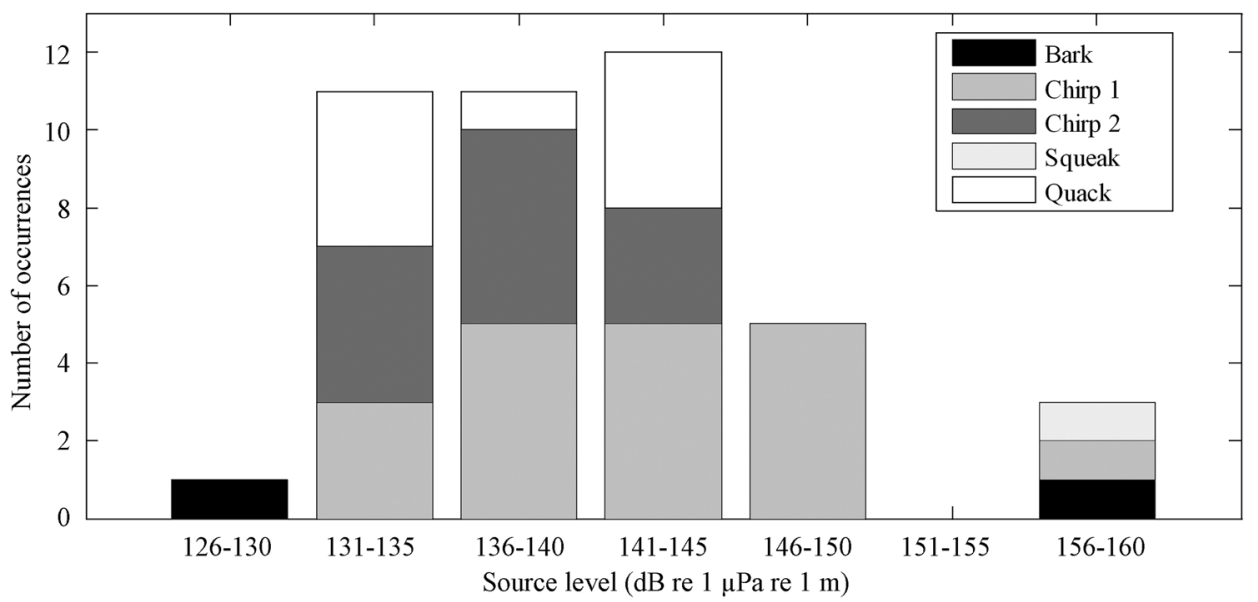

FIG. 4. Distribution of source levels (dB re $1 \mu \mathrm{Pa}$ at $1 \mathrm{~m}$ ) from recorded sound pressure levels of each call type based on estimated transmission losses of spherical spreading.

Ambient noise levels over the same frequency band as the calls, at the time of each recording set were 95, 103, and $104 \mathrm{~dB}$ re $1 \mu \mathrm{Pa}$. Taking the average SL of $139 \mathrm{~dB}$ re $1 \mu \mathrm{Pa}$ at $1 \mathrm{~m}$ means a maximum and minimum difference of 44 and $35 \mathrm{~dB}$ re $1 \mu \mathrm{Pa}$ between call and ambient noise. Assuming spherical spreading as a maximum transmission loss for each call would result in an estimate of approximately 150 and $50 \mathrm{~m}$ as minimum ranges for these conditions, respectively, before the signal attenuated to ambient noise levels (this range would be extended if estimated over a narrower bandwidth than the $200-18000 \mathrm{~Hz}$ used here).

\section{DISCUSSION}

The SLs of dugong calls reported here $(139 \mathrm{~dB}$ re $1 \mu \mathrm{Pa}$ at $1 \mathrm{~m}$ ) are comparable with those observed by

Ichikawa et al. (2011), in Thailand of $134 \mathrm{~dB}$ re $1 \mu \mathrm{Pa}$ at $1 \mathrm{~m}$, as was the SL variation. Maximum and minimum SLs in the Shark Bay calls were 159 and $129 \mathrm{~dB}$ re $1 \mu \mathrm{Pa}$ at $1 \mathrm{~m}$, respectively, with standard deviation of $6 \mathrm{~dB}$ over all calls, while Ichikawa et al. (2011) reported maximum and minimum levels of 159 and $104 \mathrm{~dB}$ re $1 \mu \mathrm{Pa}$ at $1 \mathrm{~m}$, respectively, with standard deviation of $9 \mathrm{~dB}$. It should be noted that in each case recordings were taken at $90^{\circ}$ to port side of the dugongs' head. This study has not taken directionality of dugong calls into account. Branstetter et al. (2012) observed significant directionality in bottlenose dolphin (Tursiops truncatus) calls, similar to that estimated by Lammers and Au (2003), who modeled Hawaiian spinner dolphins (Stenella longirostris) as signals produced by a circular piston transducer. These calls would decrease in level from on-axis to at $90^{\circ}$ by 6.3 and $10.8 \mathrm{~dB}$ re $1 \mu \mathrm{Pa}$ at

TABLE I. Source level data for each type of call recorded, reported as mean squared pressure levels ( $\mathrm{dB}$ re $1 \mu \mathrm{Pa}$ at $1 \mathrm{~m}$ ), maximum SELs (dB re $1 \mu \mathrm{Pa}^{2} \mathrm{~s}$ at $1 \mathrm{~m}$ ), and peak to peak pressure ( $\mathrm{dB}$ re $1 \mu \mathrm{Pa}$ at $1 \mathrm{~m}$ ). Values in parentheses for the call type column are the sample number and elsewhere are standard deviation, maximum and minimum values.

\begin{tabular}{|c|c|c|c|c|c|c|}
\hline $\begin{array}{l}\text { Call type } \\
(n)\end{array}$ & $\begin{array}{l}\text { Dugong } \\
\qquad(n)\end{array}$ & $\begin{array}{c}\text { SPL max } \\
(\mathrm{dB} \text { re } 1 \mu \mathrm{Pa} \text { at } 1 \mathrm{~m})\end{array}$ & $\begin{array}{c}\mathrm{SPL} \\
(\mathrm{dB} \text { re } 1 \mu \mathrm{Pa} \text { at } 1 \mathrm{~m})\end{array}$ & $\begin{array}{c}\text { SEL } \\
\left(\mathrm{dB} \text { re } 1 \mu \mathrm{Pa}^{2} \mathrm{~s} \text { at } 1 \mathrm{~m}\right)\end{array}$ & $\begin{array}{c}\mathrm{p}-\mathrm{p} \\
(\mathrm{dB} \text { re } 1 \mu \mathrm{Pa} \text { at } 1 \mathrm{~m})\end{array}$ & $\begin{array}{l}\text { Duration } \\
\text { (s) }\end{array}$ \\
\hline All calls (43) & All & $\begin{array}{c}150 \\
(6.3,165,138)\end{array}$ & $\begin{array}{c}139 \\
(7.1,159,129)\end{array}$ & $\begin{array}{c}124 \\
(8.2,146,110)\end{array}$ & $\begin{array}{c}155 \\
(7.1,180,145)\end{array}$ & $\begin{array}{c}0.13 \\
(0.07,0.58,0.01)\end{array}$ \\
\hline Chirp 1 (19) & $1(19)$ & $\begin{array}{c}152 \\
(5.8,161,138)\end{array}$ & $\begin{array}{c}139 \\
(6.8,159,131)\end{array}$ & $\begin{array}{c}125 \\
(8.7,146,110)\end{array}$ & $\begin{array}{c}159 \\
(7.2,180,145)\end{array}$ & $\begin{array}{c}0.1 \\
(0.09,0.37,0.01)\end{array}$ \\
\hline \multirow[t]{3}{*}{ Chirp 2 (12) } & All (12) & $\begin{array}{c}146 \\
(4.9,154,138)\end{array}$ & $\begin{array}{c}135 \\
(3.5,144,132)\end{array}$ & $\begin{array}{c}122 \\
(5.0,128,110)\end{array}$ & $\begin{array}{c}152 \\
(4.5,159,145)\end{array}$ & $\begin{array}{c}0.11 \\
(0.04,0.20,0.07)\end{array}$ \\
\hline & $1(3)$ & $\begin{array}{c}148 \\
(3.8,138,132)\end{array}$ & $\begin{array}{c}136 \\
(3.2,138,132)\end{array}$ & $\begin{array}{c}123 \\
(4.9,128,118)\end{array}$ & $\begin{array}{c}153 \\
(3.9,158,151)\end{array}$ & $\begin{array}{c}0.11 \\
(0.04,0.2,0.07)\end{array}$ \\
\hline & $2(9)$ & $\begin{array}{c}146 \\
(5.3,153,138)\end{array}$ & $\begin{array}{c}138 \\
(3.7,144,132)\end{array}$ & $\begin{array}{c}121 \\
(5.2,126,110)\end{array}$ & $\begin{array}{c}151 \\
(4.9,159,145)\end{array}$ & $\begin{array}{c}0.11 \\
(0.04,0.2,0.07)\end{array}$ \\
\hline \multirow[t]{3}{*}{ Bark (2) } & All (2) & $\begin{array}{c}159 \\
(3.7,162,157)\end{array}$ & $\begin{array}{c}143 \\
(20.8,159,129)\end{array}$ & $\begin{array}{c}129 \\
(9.2,135,122)\end{array}$ & $\begin{array}{c}164 \\
(10.5,172,157)\end{array}$ & $\begin{array}{c}0.18 \\
(0.05,0.22,0.14)\end{array}$ \\
\hline & $1(1)$ & 162 & 159 & 135 & 172 & 0.22 \\
\hline & $3(1)$ & 157 & 129 & 122 & 157 & 0.14 \\
\hline Squeak (1) & $1(1)$ & 165 & 158 & 145 & 171 & 0.58 \\
\hline \multirow[t]{3}{*}{ Quack (9) } & All (9) & $\begin{array}{c}150 \\
(6.1,153,142)\end{array}$ & $\begin{array}{c}136 \\
(5.4,143,132)\end{array}$ & $\begin{array}{c}119 \\
(12.1,128,111)\end{array}$ & $\begin{array}{c}156 \\
(7.9,160,149)\end{array}$ & $\begin{array}{c}0.06 \\
(0.06,0.1,0.02)\end{array}$ \\
\hline & $1(8)$ & $\begin{array}{c}149 \\
(4.4,154,142)\end{array}$ & $\begin{array}{c}139 \\
(3.9,143,132)\end{array}$ & $\begin{array}{c}122 \\
(6.4,128,110)\end{array}$ & $\begin{array}{c}156 \\
(4.4,160,148)\end{array}$ & $\begin{array}{c}0.06 \\
(0.06,0.1,0.02)\end{array}$ \\
\hline & $2(1)$ & 142 & 135 & 111 & 149 & 0.04 \\
\hline
\end{tabular}


TABLE II. Frequency characteristics for each call type. Chirp and squeak calls were all narrowband with fundamentals which varied in frequency during the call. Squeak, bark, and quack calls all contained broadband signals. Peak frequencies have been shown for these call types, together with the $6 \mathrm{~dB}$ bandwidth and $10 \mathrm{~dB}$ bandwidth.

\begin{tabular}{|c|c|c|c|c|c|c|}
\hline \multirow[b]{2}{*}{ Call type $(n)$} & \multirow[b]{2}{*}{ Dugong $(n)$} & \multicolumn{3}{|c|}{ Frequencies of the fundamental $( \pm$ s.d.; Hz) } & \multicolumn{2}{|c|}{ Bandwidth (Hz) } \\
\hline & & Start & Peak & End & $6 \mathrm{~dB}$ limit & $10 \mathrm{~dB}$ limit \\
\hline Chirp 1 (19) & $1(19)$ & $3078(775)$ & 3677 (517) & $3153(775)$ & & \\
\hline \multirow[t]{3}{*}{ Chirp 2 (12) } & All (12) & 3412 (119) & $3412(119)$ & $2872(113)$ & & \\
\hline & $1(3)$ & 3549 (182) & 3549 (182) & $3011(82)$ & & \\
\hline & $2(9)$ & 3324 (137) & 3324 (137) & $2787(123)$ & & \\
\hline Squeak (1) & $1(1)$ & 1853 & 2723 & 1910 & $1800-2850$ & $150-5560$ \\
\hline \multirow[t]{3}{*}{ Bark (2) } & All (2) & & $1825(25)$ & & $900-4600$ & $625-15500$ \\
\hline & $1(1)$ & & 1850 & & $1300-7000$ & $800-22000$ \\
\hline & $3(1)$ & & 1800 & & $500-2200$ & $450-8000$ \\
\hline \multirow[t]{3}{*}{ Quack (9) } & All (9) & & 2735 (253) & & $1900-3900$ & $1000-10000$ \\
\hline & $1(8)$ & & $2200(787)$ & & $1475-2640$ & $800-6700$ \\
\hline & $2(1)$ & & 2600 & & $1400-4050$ & $500-8000$ \\
\hline
\end{tabular}

10 and $20 \mathrm{kHz}$, respectively. Given that the dugong calls reported here contained energy up to around $18 \mathrm{kHz}$ the SLs should be noted as being taken perpendicular to the animals' body.

While the sample size of individual call types is comparatively small, these calls were recorded at close verifiable range. The close range significantly improves the confidence limits by reducing the effects of unknown transmission losses and improving confidence levels in localization, two factors which can have considerable impact on estimating SLs of marine animal calls (Parsons et al., 2009; Gavrilov et al., 2011). While the individual call type characteristics have been presented for each dugong, given the small number of calls of the same call type it is not feasible to draw conclusions from any comparisons between the dugongs.

The dugong calls RMS SLs are considerably lower than those of other marine mammals. The great whales can produce calls of $180-189 \mathrm{~dB}$ re $1 \mu \mathrm{Pa}$ (blue whales: Cummings and Thompson, 1971; Thode et al., 2000; McDonald et al., 2001; Širović et al., 2007), 151-173 dB re $1 \mu \mathrm{Pa}$ (humpback whales: Au, 2007; Gavrilov et al., 2011), or 159-189 dB re $1 \mu \mathrm{Pa}$ (fin whales: Watkins, 1981; Charif et al.; 2002; Širović et al., 2007), even mammals closer to the size of dugongs are significantly louder, such as killer whales (Orcinus orca, $155.3 \mathrm{~dB}$; Holt et al., 2008), bottlenose dolphins (Tursiops sp., $147 \mathrm{~dB}$ re $1 \mu \mathrm{Pa}$; Jensen et al., 2012), or white-beaked dolphins (Lagenorhynchus albirostris, $147 \mathrm{~dB}$ re $1 \mu \mathrm{Pa}$; Rasmussen et al., 2006). While a direct comparison with these calls is not possible, as the stated source levels for odontocetes do not include echolocation signals, it does provide an indication how comparatively low level the dugong calls are. The larger mammals have a more widely dispersed social group and communicate over ranges of up to tens to thousands of kilometers (Jensen et al., 2012) where lower frequency and greater call SL is advantageous. Dugongs, however, spend over $72 \%$ of their time in waters of less than $1 \mathrm{~m}$ depth (Chilvers et al., 2004). In such shallow waters transmission losses are greater and possibly communication ranges are substantially reduced (Urick, 1983). Coupled with their predominantly solitary behavior (Anderson, 1998) the low SLs of dugong calls were to be expected. The result of the SLs, combined with likely transmission losses in shallow, sandy waters is to limit communication ranges to between tens and hundreds of meters.

While reports of SLs from marine fauna often also estimate call propagation ranges from empirically determined transmission losses (Širović et al., 2007; Jensen et al., 2012) these have considered losses either along simple bathymetry profiles or propagation of sound in deep water. In Shark Bay dugongs can be found at various locations in shallow waters of complex bathymetry, comprising banks, flats, and channels (Holley, 2006). In shallow waters, propagation of high frequency signals such as dugong calls is highly dependent on the bathymetry profile and caller altitude in the water column. Therefore the modeling of dugong call propagation in Shark Bay has been the subject of a subsequent study to this report.

\section{ACKNOWLEDGMENTS}

This study was conducted as an additional component of the Department of Environment and Conservation and James Cook University's tagging of dugong in Shark Bay and the authors would like to thank both groups for their support. Members of the Shark Bay Ecosystem Research Project, led by Cindy Bessey have provided fantastic logistical support for the study.

Anderson, P. K. (1986). "Dugongs of Shark Bay, Australia-Seasonal migration, water temperature, and forage," Nat. Geog. Res. 2, 473-490.

Anderson, P. K. (1998). "Shark Bay dugongs (Dugong dugon) in summer. II: Foragers in a Halodule-dominated community," J. Mammal. 62, 409-425.

Anderson, P. K., and Barclay, R. M. R. (1995). "Acoustic signals of solitary dugongs: Physical characteristics and behavioral correlates," J. Mammal. 76, 1226-1237.

Au, W. W. L., Pack, A. A., Lammers, M. O., Herman, L. M., Deakos, M. H., and Andrews, K. (2007). "Acoustic properties of humpback whale songs,” J. Acoust. Soc. Am. 120, 1103-1110.

Branstetter, B. K., Moore, P. W., Finneran, J. J., Tormey, M. N., and Aihara, H. (2012). "Directional properties of bottlenose dolphin (Tursiops truncatus) clicks, burst-pulse, and whistle sounds," J. Acoust. Soc. Am. 131, 1613-1621.

Charif, R. A., Mellinger, D. K., Dunsmore, K. J., Fristrup, K. M., and Clark, C. W. (2002). "Estimated source levels of fin whale (Balaenoptera 
physalus) vocalizations: Adjustments for surface interference," Marine Mammal Sci. 18, 81-98.

Chilvers, B. L., Delean, S., Gales, N. J., Holley, D. K., Lawler, I. R., Marsh, H., and Preen, A. R. (2004). "Diving behavior of dugongs, Dugong dugon," J. Exp. Bio. Ecol. 304, 203-224.

Cummings, W. C., and Thompson, P. O. (1971). "Underwater sounds from the blue whale, Balaenoptera musculus," J. Acoust. Soc. Am. 50, 1193-1198.

Deecke, V. B., Slater, P. J. B., and Ford, J. K. B. (2002). "Selective habituation shapes acoustic predator recognition in harbour seals," Nature $\mathbf{4 2 0}$, $171-173$.

Department of Environment and Conservation (2010). "Welcome to Shark Bay, World Heritage Area," Government of Western Australia, www. sharkbay.org/default.aspx?WebPageID=3D214 (Last viewed, 6/15/12).

Dexler, H., and Freund, L. (1906). "Contributions to the physiology and biology of the dugong," Am. Nat. 40, 49-72.

Gavrilov, A. N., McCauley, R. D., Salgado-Kent, C., Tripovich, J., and Burton. C. (2011). "Vocal characteristics of pygmy blue whales and their change over time," J. Acoust. Soc. Am. 130, 3651-3660.

Hishimoto, Y., Ichikawa, K., Akamatsu, T., and Arai, N. (2005). "The acoustical characteristics of dugong calls and the behavioral correlates observed in Toba aquarium," in Proceedings of the 2nd International Symposium SEASTAR2000 and Asian Bio-logging Science (The 6th SEASTAR2000 Workshop), pp. 25-28.

Holley, D. K. (2006). "Movement patterns and habitat usage of Shark Bay dugongs," Master's thesis, Edith Cowan University.

Holt, M. M., Noren, D. P., Veirs, V., Emmons, C. K., and Veirs, S. (2008). "Speaking up: Killer whales (Orcinus orca) increase their call amplitude in response to vessel noise," J. Acoust. Soc. Am. 125, EL27-EL32.

Ichikawa, K., Akamatsu, T., Adulyanukosol, K., Lanyon, J., and Nawata, H. (2012). "Intraspecific variation in vocal repertoire among dugong populations," J. Acoust. Soc. Am. 131, 3456.

Ichikawa, K., Akamatsu, T., Shinke, T., and Adulyanukosol, K. (2010). "Spatial distribution of dugongs by acoustic and visual observation in Thailand," Proceedings of the 9th SEASTAR2000, pp. 39-42.

Ichikawa, K., Akamatsu, T., Shinke, T., Adulyanukosol, K., and Arai, N. (2011). "Callback response of dugongs to conspecific chirp playbacks," J. Acoust. Soc. Am. 129, 3623-3629.

Ichikawa, K., Akamatsu, T., Shinke, T., Arai, N., Hara, T., and Adulyanukosol, K. (2003). "Acoustical analyses on the calls of dugong," Proceedings of the 4th SEASTAR 2000 Workshop, pp. 72-76.

Ichikawa, K., Akamatsu, T., Shinke, T., Sasamori, K., Miyauchi, Y., Abe, Y., Adulyanukosol, K., and Arai, N. (2009). "Detection portability of vocalizing dugongs during playback of conspecific calls," J. Acoust. Soc. Am. 126, 1954-1959.

Ichikawa, K., Tsutsumi, C., Arai, N., Akamatsu, T., Shinke, T., Hara, T., and Adulyanukosol, K. (2006). "Dugong (Dugong dugon) vocalization patterns recorded by automatic underwater sound monitoring systems," J. Acoust. Soc. Am. 119, 3726-3733.

Janik, V. M., Sayigh, L. S., and Wells, R. S. (2006). "Signature whistle shape conveys identity information to bottlenose dolphins," Proc. Natl. Acad. Sci. U.S.A. 103, 8293-8297.

Jensen, F. H., Beedholm, K., Bejder, L., and Madsen, P. T. (2012). "Estimated communication range and energetic cost of bottlenose dolphin whistles in a tropical habitat," J. Acoust. Soc. Am. 131, 582-592.

Lammers, M. O., and Au, W. W. L. (2003). "Directionality in the whistles of Hawaiian spinner dolphins (Stenella longirostris)," Marine Mammal Sci. 19(2), 249-264.

Malme, C. I., Smith, P. W. J., and Miles, P. R. (1986). "Characterisation of geophysical acoustic survey sounds," OCS Study MMS-86-0032, Prepared by BBN Laboratories, Inc., Cambridge, for Battelle Memorial
Institute to the Department of the Interior, Mineral Management Service, Pacific Outer Continental Shelf Region, Los Angeles.

Marsh, H. (2008). "Dugong dugon," in IUCN 2012, IUCN Red List of Threatened Species, Version 2012.1, www.iucnredlist.org (Last viewed 7/20/12).

Marsh, H., Eros, C., Penrose, H., and Hughes, J. (2002). "Dugong status report and action plans for countries and territories," UNEP Early Warning Assessment Report Series, Vol. 1.

Marsh, H., Spain, A. V., and Heinsohn, G. E. (1978). "Minireview: Physiology of the dugong," Comp. Biochem. Physiol. 61, 159-168.

McDonald, M. A., Calambokidis, J., Teranishi, A. M., and Hildebrand, J. A. (2001). "The acoustic calls of blue whales off California with gender data," J. Acoust. Soc. Am. 109, 1728-1735.

Okumura, N., Ichikawa, K., Akamatsu, T., Arai, N., Shinke, T., Hara, T., and Adulyanukosol, K. (2007). "Stability of call sequence in Dugongs' vocalization," in Proceedings of OCEANS'06 Asia Pacific, Vol. 19, pp. $12-15$.

Parsons, M. J. G., McCauley, R. D., Mackie, M., and Duncan, A. J. (2012). "In situ source levels of mulloway (Argyrosomus japonicus) calls," J. Acoust. Soc. Am. 132(5), 3559-3568.

Parsons, M. J. G., McCauley, R. D., Mackie, M., Siwabessy, P. J., and Duncan, A. J. (2009). "Localisation of individual mulloway (Argyrosomus japonicus) within a spawning aggregation and their behaviour throughout a diel spawning period,” ICES J. Mar. Sci. 66, 1007-1014.

Piggins, D. W., Muntz, R. A., and Best, R. C. (1983). "Physical and morphological aspects of the eye of the manatee Trichechus inunguis NATTERER 1883 (Sirenia: mammalia)," Mar. Behav. Physiol. 9, 111-130.

Pollock, K. H., Marsh, H., Lawler, I. R., and Aldredge, M. W. (2004). "Improving the accuracy of aerial surveys for dugongs. Final report," AFMA/JCU final report, Canberra, Australia.

Pollock, K. H., Marsh, H., Lawler, I. R., and Aldredge, M. W. (2006). "Estimating animal abundance in heterogeneous environments: an application to aerial surveys for dugongs," J. Wild. Man. 70, 255-262.

Rasmussen, M. H., Lammers, M., Beedholm, K., and Miller, L. A. (2006). "Source levels and harmonic content of whistles in whitebeaked dolphins (Lagenorhynchus albirostris)," J. Acoust. Soc. Am. 120, 510-517.

Sirović, A., Hildebrand, J. A., and Wiggins, S. (2007). "Blue and fin whale call source levels and propagation range in the Southern Ocean," J. Acoust. Soc. Am. 122 1208-1215.

Sousa-Lima, R. S., Paglia, A. P., and Da Fonseca, G. A. B. (2002). "Signature information and individual recognition in the isolation calls of Amazonian manatees, Trichechus inunguis (Mammalia: Sirenia)," Anim. Behav. 63, 301-310.

Thode, A. M., D'Spain, G. L., and Kuperman, W. A. (2000). "Matched-field processing, geoacoustic inversion, and source signature recovery of blue whale vocalizations," J. Acoust. Soc. Am. 107, 1286-1300.

Urick, R. J. (1983). Principles of Underwater Sound, 3rd ed. (McGraw-Hill, New York), 451 pp.

Walker, D. I., Kendrick, G. A., and McComb, A. J. (1988). "The distribution of seagrass species in Shark Bay, Western Australia, with notes on their ecology," Aquat. Bot. 30, 305-317.

Watkins, W. A. (1981). "Activities and underwater sounds of fin whales," Sci. Rep. Whales Res. Inst. 33, 83-117.

Wirsing, A. J., Heithaus, M. R., and Dill, L. M. (2007a). "Living on the edge: dugongs prefer to forage in microhabitats that allow escape from rather than avoidance of predators," Ani. Behav. 74, 93-101.

Wirsing, A. J., Heithaus, M. R., and Dill, L. M. (2007b). "Fear factor: Do dugongs (Dugong dugon) trade food for safety from tiger sharks (Galeocerdo cuvier)?," Behav. Ecol. 153, 1031-1040. 